\title{
Cancer Chemoprevention Effects of Geldanamycin and 17-AAG in Human Oral Squamous Cell Carcinoma
}

\author{
Eun Ju Lee
}

Department of Clinical Laboratory Science, Daejeon Health Science College, Daejeon, Korea

\section{Geldanamycin과 17-AAG가 구강편평세포암종 세포주에 미치는 암예방 효과}

\author{
이은주 \\ 대전보건대학교 임상병리과
}

\begin{abstract}
HSP90 regulates various proteins involved in differentiation and cell survival. Levels of HSP90 tend to increase during development of squamous cell carcinoma in the head and neck including the mouth. Thus, many studies have been conducted to treat these cancers through suppression of HSP90. This study investigated the effect of two HSP90 inhibitors, geldanamycin and 17-AAG, on the proliferation, apoptosis, and invasion of human oral squamous cell carcinoma cells. Cell survival and cell cycle analyses, as well as western blot analysis, were performed with oral cancer cell lines, YD-10B and YD-38. After treatment with HSP90 inhibitors, cell proliferation was significantly inhibited. When YD-10B and YD-38 cells were treated with various concentrations of geldanamycin and 17-AAG $(0,0.1,0.3,1$ and $10 \mu \mathrm{M})$ for $24 \mathrm{hr}$, the growth of YD-10B cells was markedly reduced compared to that of YD-38 cells. Thereafter, the cells were subjected to flow cytometry, which revealed $\mathrm{G} 2$ arrest. These results demonstrated that geldanamycin induced $\mathrm{G} 2$ arrest and inhibited cell proliferation through the p-GSK-3 $\beta$ pathway in YD-10B and YD-38 cells, thus inhibiting cell survival. HSP90 inhibitors are therefore expected to have a therapeutic effect on various cancer cell lines.
\end{abstract}

Key words: Cell proliferation, Geldanamycin, Glycogen synthase kinase 3-beta

This is an Open Access article distributed under the terms of the Creative Commons Attribution Non-Commercial License (http://creativecommons.org/licenses/by-nc/4.0) which permits unrestricted non-commercial use, distribution, and reproduction in any medium, provided the original work is properly cited.

Copyright ( 2018 The Korean Society for Clinical Laboratory Science. All rights reserved.
Corresponding author: Eun Ju Lee Department of Clinical Laboratory Science, Daejeon Health Science College, 21 Chungjeong-ro, Dong-gu, Daejeon 34504 Korea

Tel: 82-42-670-9163

Fax: 82-42-670-9160

E-mail: e16lee@hit.ac.kr

Received: August 16, 2018

Revised: September 11, 2018

Accepted: September 13, 2018

\section{INTRODUCTION}

In recent years, anticancer drug development programs have been focused on molecular targeted therapy [1-3]. Trends in anticancer drug research have changed from general cytotoxic drugs to targeted cancer drugs that affect gene synthesis through regulation of proteins such as kinases related to cancer cells [1-3]. To date, a number of drugs have been developed with the goal of attaining maximal anticancer effects with minimal adverse reactions. However, most cancers have specific mutations in multiple molecules. Hence, it may be insufficient to target the mutations of a single molecule since only a subset of tumors in which the target protein has an essential role may be treated effectively [4-5]. To address these issues, the drug should be targeted to the mechanism 
that enables cancer cells to function in spite of their abnormality. Heat shock proteins 90 (HSP90) is a core component of the mechanism required for normal functions and stabilization of various signaling proteins that are mutagenic, mixed or overexpressed, promoting growth and survival of cancer cells. Moreover, since the activation level of HSP90 is different between tumors and normal cells, HSP90 inhibitors can have a high selectivity for tumor cells. For uncontrolled proliferation and abnormal growth, cancer cells modify an extremely small number of proteins, which are mostly kinases that function in signal transduction pathways [6-10]. Although tumors can be found in the same tissue, their target proteins should be changed according to the cause, and, accordingly, an inhibitor should have specific selectivity for the target protein.

17-Allylamino-17-demethoxygel-danamycin (17-AAG) targets the mechanism that enables cancer cells to function through the regulation of HSP90. Currently, the potential and efficacy of 17-AAG for anticancer treatment are being investigated in a clinical trial. Moreover, tumor cells and normal cells have a different level of HSP90 activation; thus, an HSP90 inhibitor can have a high selectivity for tumor cells. Some have argued against the use of HSP90 as a drug target, because the drug could damage normal cellular function by affecting essential chaperones such as HSP90, leading to critical side-effects [11-13]. According to the results of a phase I clinical trial, patients with 17-AAG administration showed a tolerable level of toxicity, and there could be some pharmacokinetic changes in the expression level of HSP90 target proteins.

Since the anticancer effects of 17-AAG have been investigated in phase I clinical trials only, a limited amount of information for the clinical response of cancer patients is available. According to the report to date, 17-AAG stabilized disease, which was particularly prominent in malignant melanoma. Such an effect is consistent with the inhibitory effect of 17-AAG on cell proliferation [12-14].

The present study investigated the molecular biological mechanism of cancer chemoprevention focusing on a signaling network of heat shock proteins (HSP) and glycogen synthase kinase 3-beta (GSK-3 $\beta$ ) in oral cancer using geldanamycin and 17-AAG. This is currently being investigated in a clinical trial. Furthermore, this study revealed the role of networks between HSP and GSK-3 $\beta$ during anticarcinogenesis using various anticancer drugs in order to provide a theoretical foundation for inhibition of carcinogenesis.

\section{MATERIALS AND METHODS}

\section{Cell lines}

YD-10B and YD-38 are the oral cancer cell lines, which were established using oral squamous cell carcinoma tissue from patients in the Department of Oral Pathology at Yonsei University College of Dentistry [9]. The cells were cultured in DMEM:F-12 (1:1) media containing $1 \times 10^{10} \mathrm{M}$ choleratoxin, $0.4 \mathrm{mg} / \mathrm{mL}$ hydrocortisone, $5 \mu \mathrm{g} / \mathrm{mL}$ insulin, $5 \mu \mathrm{g} / \mathrm{mL}$ transferrin, $2 \times 10^{11} \mathrm{M}$ triiodothyronine (T3) supplemented with $10 \% \mathrm{FBS}$ using a $5 \% \mathrm{CO}_{2}$ incubator at $37^{\circ} \mathrm{C}[9]$.

\section{HSP90 inhibitors}

Geldanamycin and 17-AAG, a geldanamycin derivative, were used as HSP90 inhibitors (Figure 1).

\section{Measurement of cell growth rate}

To measure the survival rate of YD-10B and YD-38 cells after treatment with geldanamycin or 17-AAG, $2 \times 10^{3}$ cells of each line in $100 \mu \mathrm{L}$ media were distributed to each of the 96 well plates and cultured for $24 \mathrm{hr}$, followed by treatment with geldanamycin or $17-\mathrm{AAG}$ at $0-100 \mu \mathrm{M}$ of concentration within media containing $10 \%$ FBS and then
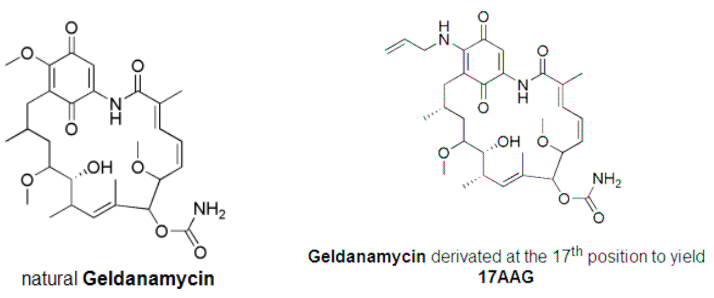

Figure 1. Chemical structures of geldanamycin and 17-AAG. 
incubated at $37^{\circ} \mathrm{C}$ for $24 \mathrm{hr}$ or $48 \mathrm{hr}$. Thereafter, the 96 well plates were washed with phosphate buffered saline (PBS) buffer. Following this, $10 \mu \mathrm{L}$ of the cell counting kit-8 (CCK-8) solution was added to the media and incubated in $5 \% \mathrm{CO}_{2}$ incubator at $37^{\circ} \mathrm{C}$ for $1-4 \mathrm{hr}$. After the reaction, optical density (OD) at $450 \mathrm{~nm}$ was measured by using an ELISA reader (Bio-Tek Instruments Inc., Winooski, VT, USA).

\section{Measurement of cell cycle}

To monitor the changes in the cell cycles of YD-10B and YD-38 cells depending on geldanamycin or 17-AAG treatments, the cells were treated with $0,0.1,1$, or $5 \mu \mathrm{M}$ of geldanamycin or 17-AAG for $24 \mathrm{hr}$ once they colonized 50 $60 \%$ larger. Thereafter, cells were isolated by centrifugation and fixed with 100\% ethyl alcohol (Sigma, St. Louis MO, USA). The fixed cells were washed with PBS two times in order to completely remove the 100\% ethyl alcohol, mixed with RNase A (Amresco, Cleveland, OH, USA) that was diluted 8 -fold in PBS, and incubated at $37^{\circ} \mathrm{C}$ for 30 min. Thereafter, nuclear DNAs were stained with propidium iodide (PI, Sigma St. Louis MO, USA). Immediately after staining, cells were subjected to flow cytometry (FACS, Becton Dickinson, San Jose, CA, USA) to analyze the cell cycle.

\section{Expression of proteins related to the cell cycle and signal transduction}

To investigate the expression of proteins involved in cell proliferation and cell cycle regulation, $2 \times 10^{4}$ cells of YD-10B and YD-38 lines were seeded to 6-well plates and cultured, which were then treated with $0,0.1,1$, and 10 $\mu \mathrm{M}$ concentrations of geldanamycin or 17-AAG for $24 \mathrm{hr}$. Thereafter, proteins were isolated with RIPA buffer, of which $30 \mu \mathrm{g}$ of protein was applied to electrophoresis.
Following this, p21CIP1/WAF1 (Delta Biolabs, Gilroy, CA, USA) and p27KIP1 (Santa Cruz Biotechnology, Delaware Avenue, CA, USA), which are regulatory proteins of cell growth, were incubated with primary antibodies after

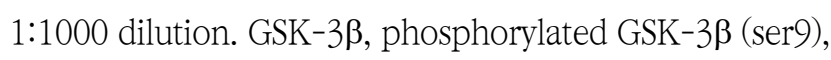
and phosphorylated GSK-3 $\beta$ (Y216) (BD bioscience, San Jose CA, USA) were diluted for use following the manual instructions. Secondary antibodies compatible with the primary antibodies were diluted 1:2000, and incubated for $1 \mathrm{hr}$, followed by ECL reaction, on which $\mathrm{x}$-ray film was exposed and then developed.

\section{Statistical analysis}

Experiments were repeated three times, and a significance of difference within the control group was tested by the two-sided t-test method. Values in this study were represented by mean and standard deviation. The threshold $P$-value for significance was 0.05 .

\section{RESULTS}

\section{Effects of geldanamycin and 17-AAG treatments on growth of oral cancer cells}

IC50 values for different cell lines are shown in Table 1. Growth of YD-10B and YD-38 cells was inhibited in a similar pattern, in which the cell growth rate decreased in a time- and concentration-dependent manner. When the cell growth rates were compared between $24 \mathrm{hr}$ and $48 \mathrm{hr}$ treatments, the IC50 value of the $48 \mathrm{hr}$ treatment was lower by approximately 100-fold than that of the $24 \mathrm{hr}$ treatment. Cell growth inhibitory effects of the 48 and 72 hr treatments were similar.

Table 1. Growth inhibition of YD-10B and YD-38 cell lines by treatment with geldanamycine or 17-AAG

\begin{tabular}{lcccc}
\hline & \multicolumn{2}{c}{ Geldanamycin $(\mu \mathrm{M})$} & \multicolumn{2}{c}{ 17-AAG $(\mu \mathrm{M})$} \\
\cline { 2 - 5 } \cline { 3 - 4 } & YD10B & YD38 & YD10B & YD38 \\
\hline 1 day & 22.912 & 18.099 & 16.977 & 14.039 \\
2 days & 0.281 & 0.288 & 0.832 & 0.981 \\
3 days & 0.319 & 0.249 & 0.861 & 0.861 \\
\hline
\end{tabular}




\section{HSP90 and GSK3 $\beta$ expression by treatments with geldanamycin or 17-AAG}

As shown in Figure 2, the expression levels of HSP90 and phosphorylated GSK- $3 \beta$ were reduced in both cell lines in a concentration-dependent manner. YD-10B cells had a higher expression level of phosphorylated GSK-3 $\beta$ than YD-38 cells; the expression level was decreased more by the geldanamycin or 17-AAG treatment compared to that in YD-38 cells. Reduction of HSP90 expression by geldanamycin or 17-AAG treatments was also more evident in YD-10B cells.

\section{Effects of geldanamycin or 17-AAG treatments on cell cycle}

As shown in Figure 3, proportions of cells in the G2 stage were higher in YD-10B and YD-38 cells after treatments with $0.1 \mu \mathrm{M}$ of either drug for $24 \mathrm{hr}$ when compared to that in untreated cells. When YD-10B cell lines were treated with geldanamycin, the proportion of cells in the G2 stage
A

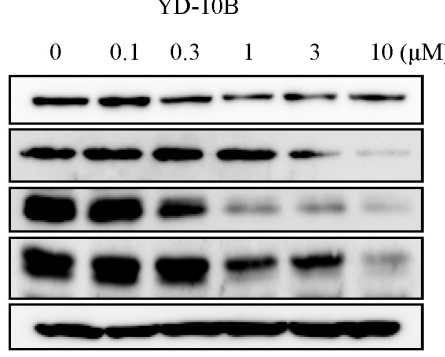

Chemical :17AAG

sample : $20 \mu \mathrm{g}$

YD-38

B
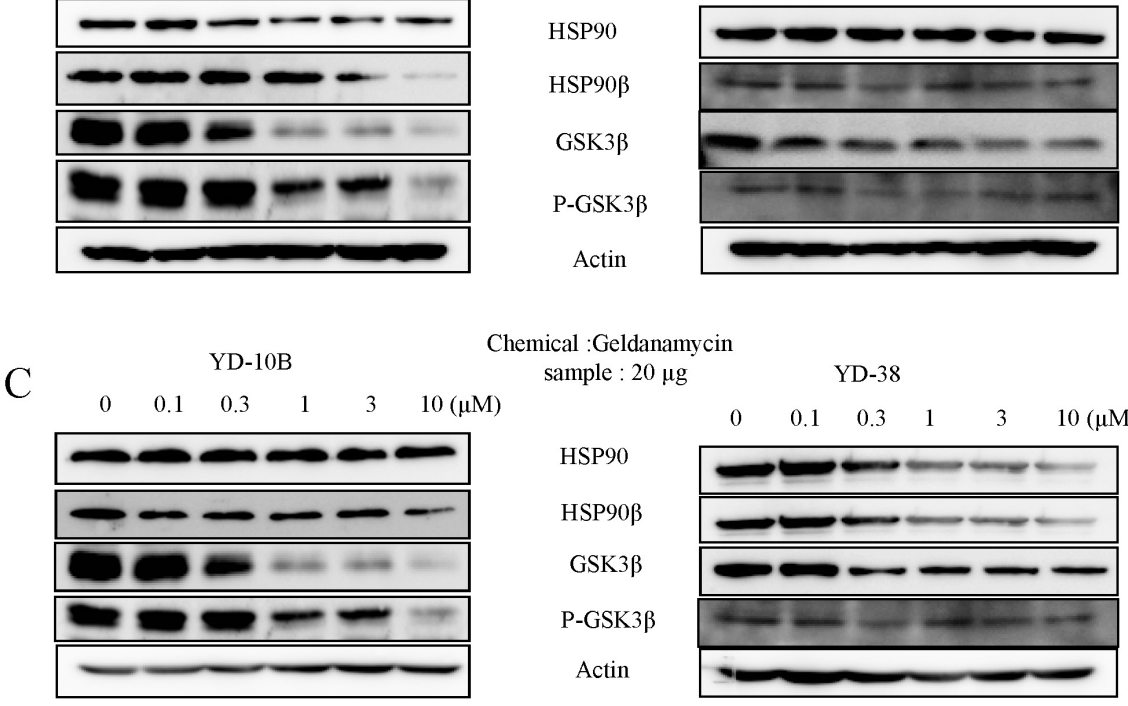

Chemical :Geldanamycin sample : $20 \mu \mathrm{g}$

YD-38

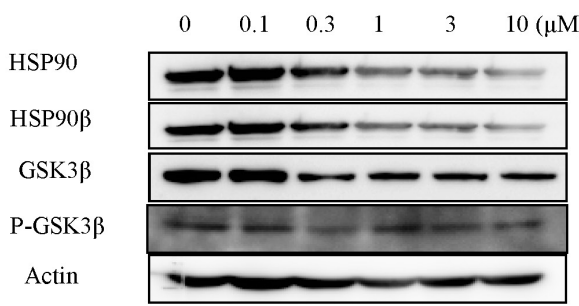

Figure 2. Expression of HSP90 and $\mathrm{D}$ $p-G S K 3-\beta$ inYD-10B and YD-38 cell lines. After treatment of $Y D-10 B$ and YD-38 cells with 17-AAG (A, B) and geldanamycin (C, D) for $24 \mathrm{hr}$, expression level of HSP90 phosphorylated GSK3- $\beta$ was examined by the western blot analysis. YD-10B cells had a higher expression level of phosphorylated GSK3- $\beta$ than YD-38 cells, and also had a more reduction by geldanamycin or 17-AAG treatment than YD-38 cells.

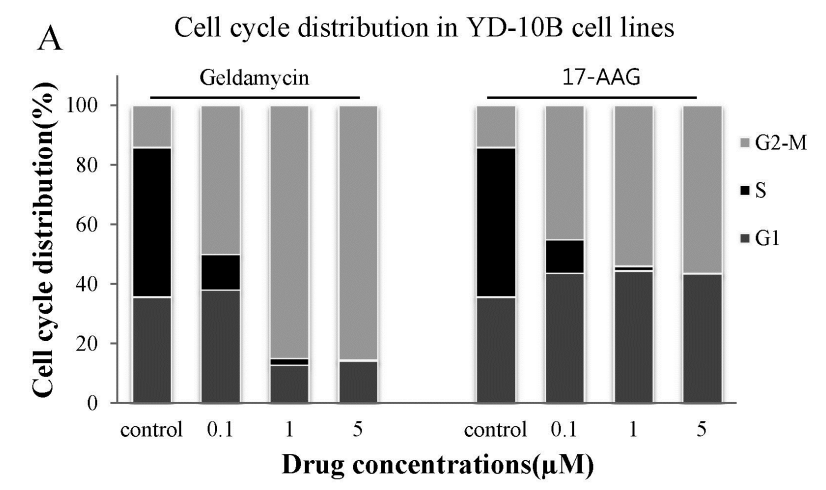

B

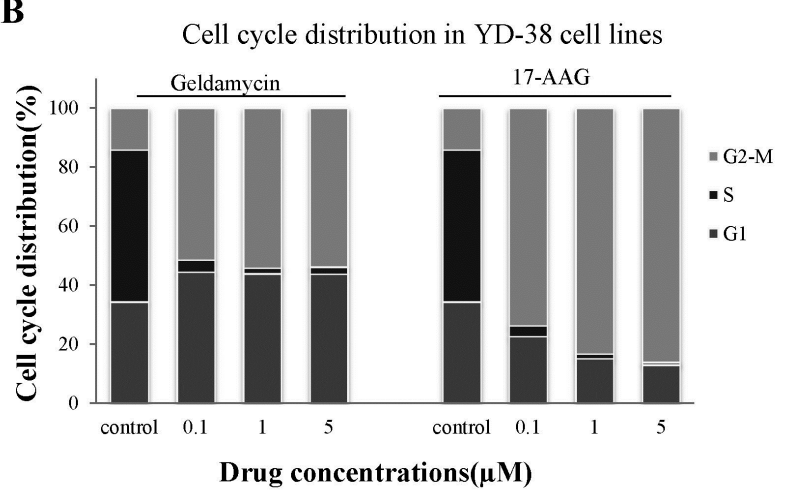

Figure 3. Cell cycle distribution of YD-10B and YD-38 cell lines after treatment with geldanamycin or 17-AAG. To examine the changes of cell cycle in YD-10B and YD-38 cells by treatment with geldanamycin or 17-AAG. YD-10B (A) and YD-38 (B) cells were treated with geldanamycin or 17-AAG for $24 \mathrm{hr}$, followed by examining cell cycle using flow cytometry. Proportions of G2 stage became higher in treated YD-10B and YD-38 cells after treatments with $0.1 \mu \mathrm{M}$ of either drug for $24 \mathrm{hr}$ than in untreated cells $(A, B)$. 
increased $50 \%$ at $0.1 \mu \mathrm{M}$ of geldanamycin and $85 \%$ at $1 \mu \mathrm{M}$. The proportion of YD-10 cells in the G2 stage was 14\% without 17-AAG treatment, whereas it increased to $45 \%$, $54 \%$ and $56 \%$ following treatments with $0.1 \mu \mathrm{M}, 1 \mu \mathrm{M}$ and $5 \mu \mathrm{M}$ of 17-AAG after $24 \mathrm{hr}$, respectively. For YD-10B cells, there were more G2 arrests by geldanamycin treatment. For YD-38 cells, the proportion of cells in the G2 stage increased to $52 \%$ and $54 \%$ after $0.1 \mu \mathrm{M}$ and $1 \mu \mathrm{M}$ of geldanamycin treatment, respectively. While the G2 stage accounted for $14 \%$ of YD-10 cells without $17-\mathrm{AAG}$ treatment, it increased to $74 \%, 83 \%$ and $86 \%$ after treatment with $0.1 \mu \mathrm{M}, 1 \mu \mathrm{M}$ and $5 \mu \mathrm{M}$ of $17-\mathrm{AAG}$ for $24 \mathrm{hr}$, respectively. In YD-38 cells, 17-AAG treatment resulted in more cells with G2 arrest. In summary, YD-10B and YD-38 cells showed G2 arrest when treated with HSP90 inhibitors, in which there was a difference depending on the drug.

\section{Changes in GSK-3 $\beta$ activity and cyclin D1}

Phosphorylated GSK-3 $\beta$ (ser9) is an inactive form of GSK- $3 \beta$, whereas phosphorylated GSK- $3 \beta$ (Y216) is its active form. As shown in Figure 4, there was no change in the expression level of phosphorylated GSK-3 $\beta$ (ser9) in YD-38 cells, whereas its level decreased in YD-10B cells after treatment with HSP90 inhibitors in a concentration-dependent manner. In addition, YD-10 and YD-38 cells showed no change in the expression level of cyclin D1. It was speculated that there should be no relationship between a reduction of GSK-3 3 in YD-10B and YD-38 cells and change in cyclin D1 level, and p21CIP1/WAF1 protein, p27KIP1 protein and CDK inhibitors of cyclinD1, affected the cell cycle regardless of its activation.

\section{DISCUSSION}

Stresses are essential for all organisms, and various stresses dramatically increase cellular synthesis of some proteins. Such proteins refer to stress proteins or HSP. When HSP maintains a basal expression level, it regulates binding of normal proteins and prevents abnormal interactions and aggregation. Elevation of HSP synthesis in response to various stresses (high temperature, heavy metal, hypoxia, acidosis, alcohol, osmotic stress etc.) is an adaptive response to enhance cell survival [10-15]. Those two functions are found in tumors. In stress conditions, survival of tumor cells is promoted, and tumor cells become resistant to environmental changes. In regard to new drug development, the idea that cancer and other diseases would be treated by a pharmacological method

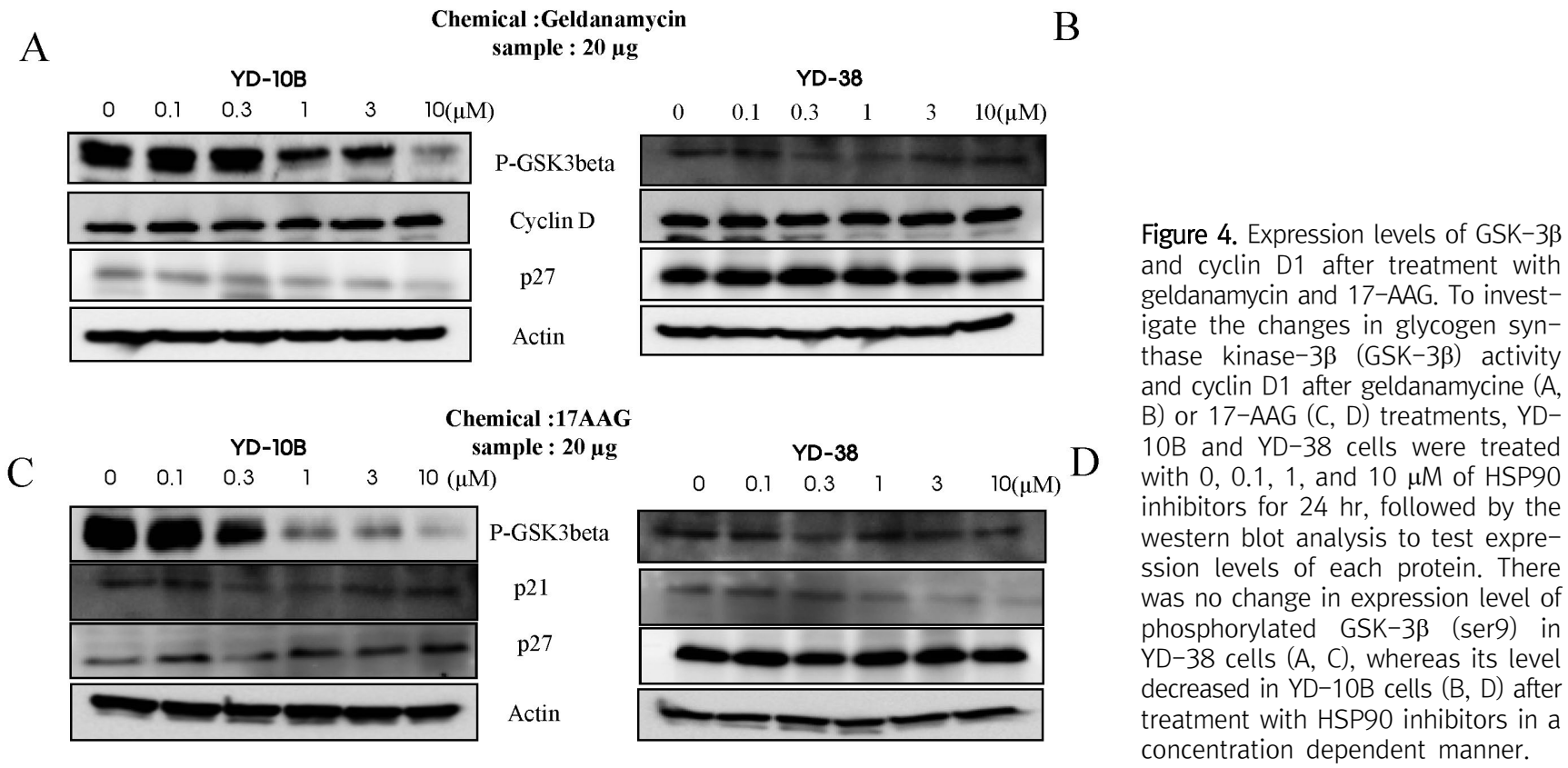


through regulation of chaperone function has drawn a lot of attention. During the recent decade, various small molecular anticancer drugs have been developed, which target HSP90, a molecular chaperone. Such drugs have an excellent inhibitory effect on the activities of various receptors, kinases, and transcription factors that are related with tumorigenesis [16-18]. Elevation of expression of one or more HSP proteins is a general characteristic of cancers such as solid tumors or malignant hepatologic tumors compared to normal tissue. Increased expression of chaperones contributes to various processes of tumorigenesis. In physiological aspects, an elevated level of HSP during carcinogenesis leads to cell protection in response to features of tumor such as hypoxia, acidosis and malnutrition in microenvironments. At the molecular level, enhanced chaperone activity enables tumor cells to respond to an imbalance in signals related to tumor transformation, leading to avoidance from subsequent apoptosis. HSP90 and co-chaperones also regulate apoptosis of tumor cells. It is speculated that such functions have anti-tumor effects by affecting the mechanism of AKT, TNF receptor and NF-kB. However, HSP90 has more complex functions in mediating tumor transformation, rather than simple inhibition of apoptosis. It has been demonstrated that HSP90 inhibitors have anticancer activity by causing cytotoxicity or inhibiting cell proliferation through cell culture experiments and animal tumor experiments. Regardless of p53 expression level, HSP90 inhibited the G1 stage in cells that had a normal cell cycle and in cancer cell lines. HSP90 also inhibited mitosis in some particular cancer cell lines, causing apoptosis [18-23]. It seemed that such effects of the HSP90 inhibitors on the cell cycle should be unrelated to the presence of a single molecule. Instead, they seemed to be related to the defects in the check point of cell cycle. While treatment with the HSP90 inhibitor increased the apoptotic effects, it remains to be revealed whether such apoptotic effects are necessary and sufficient conditions for anticancer activity of HSP90 inhibitors [18-23].

Simultaneous functionality of HSP90 inhibitors in various carcinogenesis pathways is their unique and attractive feature. However, there are some issues in the development of HSP90 inhibitors. First, inhibition of HSP90 activity at a certain stage where the tumor becomes weakened by the inhibitor leads to toxicity in most cancer cells; it can also cause mutations in some cells, resulting in enhanced viability of those cells and aggravation of cancer. Another issue is how to predict which patients could be effectively treated by HSP90 inhibition; HSP90 inhibitors have highly potent apoptotic effects on tumor specific client proteins [18-23]. In addition to client proteins, HSP90 itself and stress responses are also important factors that determine drug sensitivity. Recently, HSP90 inhibitors have been applied to other disease models (Huntington's disease and Parkinson's Disease) where chaperones have important functions in addition to tumors, in which stress responses were carefully regulated [24].

Currently, a clinical trial has been testing the potential and efficacy of 17-AAG for anticancer treatment, targeting the mechanism that operates cancer cells through regulation of HSP90. Moreover, tumor cells and normal cells have different activation states of HSP90, which is beneficial for high selectivity of HSP90 inhibitors for tumor cells. Some argue against the use of HSP90 as a drug target, because of the effects of the drug on critical chaperones such as HSP90; these cab cause detrimental side effects through damage of normal cellular functions. To date, the anticancer effect of 17-AAG has been studied at the level of phase I of the clinical trials only; therefore only a limited amount of information regarding the clinical response of cancer patients is available. According to the available report, 17-AAG maintained stabilization of diseases, particularly malignant melanoma, and such effects are consistent with the antiproliferation activity of 17-AAG [23-26].

Clinical development of HSP90 inhibitors for chemotherapy of cancer has developed rapidly. Currently, the principle of 17-AAG has been proven through various steps of phase I clinical trials, and a phase II clinical trial of 17-AAG has been implemented under the support of the NCI. There have been many interests in the potential of 
17-AAG to be used together with radiation therapy, other conventional cytotoxic drugs and materials targeting new molecules as well as in its treatment efficacy. A pre- clinical trial showed that 17-AAG sensitively responded to apoptosis caused by radiation therapy and conventional chemotherapy in cell lines from adults and children [23-25].

The present study observed an inhibition effect of cell proliferation by treatment of oral squamous cell carcinoma with HSP90 inhibitors, in which cell proliferation was inhibited through PI3K/AKT/GSK-3ß/Myc and MAP pathways. Cell culture experiment and animal tumor experiment proved that HSP90 inhibitors had anticancer activities such as induction of cytotoxicity or inhibition of cell proliferation. Regardless of p53 expression level, HSP90 inhibited G1 stage in cells with normal cell cycle and many cancer cell lines [27-28]. In some particular cancer cell lines, HSP90 caused cellular apoptosis through inhibition of mitosis. It seemed that such effects of HSP90 inhibitors on cell cycle were unrelated with presence of single molecule, whereas it should be related with the check point of cell cycle. While treatment with HSP90 inhibitors increased apoptotic effect, it has yet to be revealed whether such effects are the necessary and sufficient condition for anticancer activity of HSP90 inhibitors [27].

Since G2 arrest was induced after treatment of oral cancer cell lines with HSP90 inhibitors in this study, it should be further studied on G2 arrest related cyclin and CDK expression. In addition, since G2 arrest is related with DNA damage, it is required to study on DNA damage caused by treatment with HSP90 inhibitor [20-25].

Clinical development of HSP90 inhibitors has been rapidly progressed for application to chemotherapy for cancer. To date, the principle for 17-AAG has been proven through various steps of phase I clinical trial, and phase II clinical trial for 17-AAG has been initiated by the support of the NCI (National Cancer Institute). People were interested in potential of 17-AAG to be used in combination with radiation therapy, other conventional cytotoxic drugs and materials targeting new molecules and its efficacy, and pre-clinical trial found that 17-AAG sensitively responded to apoptosis caused by radiation therapy and conventional chemotherapy in cell lines from adults and children [20-25]. Thus, we plan to perform further study on potential of HSP90 inhibitors for concomitant application with radiation therapy, other conventional cytotoxic drugs and materials for new molecular targets as well as on their treatment efficacy.

\section{요 약}

HSP90은 세포성장, 분화, 생존에 관련된 다양한 단백질들의 안정화 및 활성조절을 담당 한다. $\mathrm{HSP} 90$ 은 구강을 포함하는 두 경부에 발생하는 편평세포암종의 발생과정에서 점진적으로 증 가하는 경향을 나타낸다. 따라서 HSP90 의 발현을 억제함으로 서 암을 치료하고자하는 연구가 많이 진행되고 있다. 본 연구에 서는 인간의 구강 편평세포암종세포에서 증식과 세포주기에 대 한 HSP90 억제제의 효과를 조사하기 위해 구강암 세포주를 대 상으로 세포의 생존능 측정, 세포주기분석, 전기영동 분석을 시 행하였다. HSP90 억제제 처리 후 세포 증식은 억제되었으며 통 계적으로 유효한 성장억제 효과를 나타났고, YD-10B세포와 YD-38세포에 Geldanamycin과 17-AAG를 0, 0.1, 0.3, 1, 10 $\mu \mathrm{M}$ 농도로 $24 \mathrm{hr}$ 처리한 결과 $\mathrm{YD}-38$ 에 비해 YD-10B세포가 세포 성장이 현저하게 감소하는 것을 확인하였다. 그 후, 유세포 분석기로 확인해 본 결과 $\mathrm{G} 2$ arrest가 관찰되었다. 이상의 연구 결과에서 구강암 세포주 YD-10B 세포와 YD-38 세포에서 Geldanamycin은 G2 arrest를 유도하고, p-GSK-3ß pathway 를 통하여 세포증식을 억제하여 세포생존을 막는다는 것을 확 인하였다. 이를 통해 HSP90 저해제를 이용하여 다양한 암세포 주에서 치료 효과를 기대 할 수 있다고 사료된다.

Acknowledgements: This paper was supported by Daejeon Health Institute of Technology in 2016. Conflict of interest: None

Author's information (Position): Lee EJ, Professor.

\section{REFERENCES}

1. Harrington KJ, Billingham LJ, Brunner TB, Burnet NG, Chan CS, Hoskin P, et al. Guidelines for preclinical and early phase clinical assessment of novel radiosensitisers. Br J Cancer. 2011; 105:628-639. https://doi.org/10.1038/bjc.2011.240.

2. Dillon MT, Harrington KJ. Human papillomavirus-negative pharyngeal cancer. J Clin Oncol. 2015;33:3251-61. https://do- 
i.org/10.1200/JCO.2015.60.7804.

3. Trepel J, Mollapour M, Giaccone G, Neckers L. Targeting the dynamic HSP90 complex in cancer. Nat Rev Cancer. 2010;10: 537-549. https://doi.org/10.1038/nrc2887.

4. Pearl LH, Prodromou C. Structure, function, and mechanism of the HSP90 molecular chaperone. Adv Protein Chem. 2001; 59:157-186. https://doi.org/10.1016/S0065-3233(01) 59005-1.

5. Whitesell L, Lindquist SL. HSP90 and the chaperoning of cancer. Nat Rev Cancer. 2005;5:761-772. https://doi.org/10. 1038/nrc1716.

6. Neckers L. Chaperoning oncogenes: HSP90 as a target of geldanamycin. Handb Exp Pharmacol. 2006;172:259-277. https://doi.org/10.1007/3-540-29717-0_11.

7. Pacey S, Banerji U, Judson I, Workman P. HSP90 inhibitors in the clinic. Handb Exp Pharmacol. 2006;172:331-358. https:// doi.org/10.1007/3-540-29717-0_14.

8. Schulte TW, Blagosklonny MV, Ingui C, Neckers L. Disruption of the Raf-1-HSP90 molecular complex results in destabilization of Raf-1 and loss of Raf-1-Ras association. J Biol Chem. 1995;270:24585-24588. https://doi.org/10.1074/jbc.270.41.24585.

9. Lee EJ, Kim J, Lee SA, Kim EJ, Chun YC, Ryu MH, et al. Characterization of newly established oral cancer cell lines derived from six squamous cell carcinoma and two mucoepidermoid carcinoma cells. Exp Mol Med. 2005;37:379-390. https://doi.org/10.1038/emm.2005.48.

10. Lippman SM, Hong WK. Molecular markers of the risk of oral cancer. N Engl J Med. 2001:344:1323-1326. https://doi.org/ 10.1056/NEJM200104263441710.

11. Xu W, Marcu M, Yuan X, Mimnaugh E, Patterson C, Neckers L. Chaperone-dependent E3 ubiquitin ligase CHIP mediates a degradative pathway for c-ErbB2/Neu. Proc Natl Acad Sci U S A. 2002;99:12847-12852. https://doi.org/10.1073/pnas.202365899.

12. Zhou P, Fernandes N, Dodge IL, Reddi AL, Rao N, Safran H, et al. ErbB2 degradation mediated by the co-chaperone protein CHIP. J Biol Chem. 2003;278:13829-13837. https://doi.org/10.1074/jbc.m209640200.

13. Machida H, Matsumoto Y, Shirai M, Kubota N. Geldanamycin, an inhibitor of HSP90, sensitizes human tumour cells to radiation. Int J Radiat Biol. 2003;79:973-980. https://doi.org/10.1080/09553000310001626135.

14. Noguchi M, Yu D, Hirayama R, Ninomiya Y, Sekine E, Kubota N, et al. Inhibition of homologous recombination repair in irradiated tumor cells pretreated with HSP90 inhibitor 17-allylamino-17-demethoxygeldanamycin. Biochem Biophys Res Commun. 2006;351:658-663. https://doi.org/10.1016/ j.bbrc.2006.10.094.

15. Hashida S, Yamamoto H, Shien K, Ohtsuka T, Suzawa K, Maki Y, et al. HSP90 inhibitor NVP-AUY922 enhances the radiation sensitivity of lung cancer cell lines with acquired resistance to EGFR-tyrosine kinase inhibitors. Oncol Rep. 2015;33:14991504. https://doi.org/10.3892/or.2015.3735.

16. Choi YE, Battelli C, Watson J, Liu J, Curtis J, Morse AN, et al. Sublethal concentrations of 17-AAG suppress homologous recombination DNA repair and enhance sensitivity to carboplatin and olaparib in HR proficient ovarian cancer cells. Oncotarget. 2014;5:2678-2687. https://doi.org/10.18632/oncotarget.1929.

17. Roh J-L, Kim EH, Park HB, Park JY. The HSP90 inhibitor 17-(allylamino)- 17-demethoxygeldanamycin increases cisplatin antitumor activity by inducing p53- mediated apoptosis in head and neck cancer. Cell Death Dis. 2013;4:e956. https://doi.org/10.1038/cddis.2013.488.

18. Yoshida S, Koga F, Tatokoro M, Kawakami S, Fujii Y, Kumagai J, et al. Low-dose HSP90 inhibitors tumor-selectively sensitize bladder cancer cells to chemoradiotherapy. Cell Cycle. 2011;1 0:4291-4299. https://doi.org/10.4161/cc.10.24.18616.

19. Barker HE, Patel R, McLaughlin M, Schick U, Zaidi S, Nutting $\mathrm{CM}$, et al. CHK1 inhibition radiosensitises head and neck cancers to paclitaxel-based chemoradiotherapy. Mol Cancer Ther. 2016;15:2042-2054. https://doi.org/10.1158/1535-7163.mct15-0998.

20. Friedman JA, Wise SC, Hu M, Gouveia C, Vander Broek R, et al. HSP90 inhibitor SNX5422/2112 targets the dysregulated signal and transcription factor network and malignant phenotype of head and neck squamous cell carcinoma. Transl Oncol. 2013;6:429-441. https://doi.org/10.1593/tlo.13292.

21. Suhane T, Laskar S, Advani S, Roy N, Varunan S, Bhattacharyya $\mathrm{D}$, et al. Both the charged linker region and ATPase domain of HSP90 are essential for rad51-dependent DNA repair. Eukaryot Cell. 2015;14:64-77. https://doi.org/10.1128/ec.00159-14.

22. Yin X, Zhang H, Lundgren K, Wilson L, Burrows F, Shores CG. BIIB021, a novel HSP90 inhibitor, sensitizes head and neck squamous cell carcinoma to radiotherapy. Int J Cancer. 2010; 126:1216-1225. https://doi.org/10.1002/ijc.24815.

23. Stingl L, Stühmer T, Chatterjee M, Jensen MR, Flentje M, Djuzenova CS. Novel HSP90 inhibitors, NVP-AUY922 and NVP-BEP800, radiosensitise tumour cells through cell-cycle impairment, increased DNA damage and repair protraction. Br J Cancer. 2010;102:1578-91. https://doi.org/10.1038/sj.bjc. 6605683.

24. Wenjie L, Weilin A, Tony T, Anna R, Gabriela C. Heat shock protein 90 in neurodegenerative diseases. Mol Neurodegener. 2010;5:24. https://doi.org/10.1186/1750-1326-5-24.

25. Dillon MT, Good JS, Harrington KJ. Selective targeting of the G2/M cell cycle checkpoint to improve the therapeutic index of radiotherapy. Clin Oncol (R Coll Radiol). 2014;26:257-265. https://doi.org/10.1016/j.clon.2014.01.009.

26. Zhang C-Z, Spektor A, Cornils H, Francis JM, Jackson EK, Liu S, et al. Chromothripsis from DNA damage in micronuclei. Nature. 2015;522:179-184. https://doi.org/10.1038/nature14493.

27. Wang DH, Zhang YJ, Zhang SB, Liu H, Liu L, Liu FL, et al. Geldanamycin mediates the apoptosis of gastric carcinoma cells through inhibition of EphA2 protein expression. Oncol Rep. 2014;32:2429-2436. https://doi.org/10.3892/or.2014.3542.

28. Shintani S, Zhang T, Aslam A, Sebastian K, Yoshimura T, Hamakawa H. P53-dependent radiosensitizing effects of HSP90 inhibitor 17-Allylamino-17-demethoxy geldanamycin on human oral squamous cell carcinoma cell lines. Int J Oncol. 2006; 29:1111-1117. https://doi.org/10.3892/ijo.29.5.1111. 